$\underline{\text { Research Articles }}$

\title{
Content analysis of food advertisements on popular indian television channels among children and youth: a cross-sectional study
}

\author{
Shalini Bassi ${ }^{1}$ (D, Deepika Bahl ${ }^{1}$, Heeya Maity ${ }^{1}$, Sakshi Dudeja ${ }^{1}$, Vani Sethi ${ }^{2}$ Monika Arora ${ }^{1}$ \\ ${ }^{1}$ Health Promotion Division, Public Health Foundation of India, Gurugram, Haryana, India, 2 UNICEF India, Delhi, India \\ Keywords: youth, children, advertisements, television, food \\ https://doi.org/10.29392/001c.28355
}

\section{Journal of Global Health Reports}

Vol. 5, 2021

\begin{abstract}
Background
Exposure to food marketing through television is a pathway impacting food choices and purchasing behavior among children and adolescents and can contribute to overweight and obesity. The study conducted a detailed content analysis of food advertisements on popular television channels among children and youth in India. It also explored the differences in the content of these advertisements: a) between channels (children vs youth); b) within the channel by day type (weekend and weekdays) and time.
\end{abstract}

\section{Methods}

A cross-sectional study was undertaken on six popular national television channels among children (2-14 years) and youth (>14 years). Data was collected for three consecutive weeks (September 2020) during selected hours on both weekdays and weekends (4:00pm to 10:00 pm), with additional hours (10.00am-2:00pm) on weekends, by adapting the existing validated tools. Statistical methods like Pearson's chi-squared test, Fisher's exact test, and independent t-test were used.

\section{Results}

A higher proportion of Food advertisements were seen on children's channels (38\%) than youth channels (23\%) $(P<0.001)$. By day type, no statistically significant difference was seen for Food advertisements shown on children's $(P=0.553)$ and youth channels $(P=0.513)$. Maximum advertisements were seen on weekdays between $8 \mathrm{pm}-9 \mathrm{pm}$ on children's and youth channels. Similarly, on weekends, 4 pm-5 pm for children's channels and 7 pm-8 pm for youth channels. Majority of the Food advertisements were high in fat, salt, and sugar (88.6\%) irrespective of channel (children and youth) and day type (weekend or weekday). On children's channels, food high in fat, salt and sugar were advertised more on weekends than weekdays $(P=0.006)$, but this difference was not significant on youth channels $(P=0.089)$. Of these foods, it was foods high in sugar that were seen more on children's $(55.2 \%)$ than youth channel $(41.5 \%)(P<0.001)$.

\section{Conclusions}

The study informed that advertisements targeted towards children and youth had specific timings and were majorly high in fat, salt, and sugar. There is a need for instituting systems for tracking compliance with regulations, on the content and timing of food advertisements, and developing national databases for tracking all broadcasts to periodically inform the enforcement of food advertisements targeting children and youth in India.

Globally, over 38 million children (<5 years) and 340 million children and adolescents ( $5-19$ years) were overweight and obese in $2019 .{ }^{1}$ The prevalence of overweight and obesity has increased by approximately five folds in the past 40 years. ${ }^{1}$ The rise in obesity will undermine the achievement of Sustainable Development Goal (SDG)- $3^{2}$ "ensuring healthy lives and promoting well-being for all ages" as obesity has been linked to Non-Communicable Diseases (NCDs). ${ }^{1}$

The low-and middle-income countries (LMICs) formerly confronted with a high prevalence of undernutrition (stunting or thinness) are now facing over-nutrition (overweight or obesity) as an additional burden. ${ }^{3}$ By comparing National Family Health Surveys, it has become evident that overweight or obesity has increased among adolescents (15-19 
years) in India. The prevalence of overweight or obesity among adolescent boys (15-19 years) was $1.7 \%$ in $2005-06,4$ which increased to $4.8 \%$ in $2015-16 .{ }^{5}$ Similarly, among adolescent girls (15-19 years), it was $2.4 \%{ }^{4}$ and became $4.2 \%$ in 2015-16. ${ }^{5}$ The Comprehensive National Nutrition Survey (2019) reveals that approximately $4 \%$ (4.6 million) of children (5-9 years) and 5\% (12 million adolescents) of adolescents (10-19 years) were overweight or obese in India. ${ }^{6}$

Various factors contribute to the development of overweight and obesity among children and adolescents. In addition to a genetic predisposition, the food environment greatly influences food choices, eating behavior, and nutritional status of children and adolescents. ${ }^{7-9}$ The marketing, including advertising of food and beverage high in fat, sugar, and salt (HFSS) is recognized as one of the influential environmental factors impacting an individual's behavior, leading to a rise in overweight, obesity and other diet-related NCDs. ${ }^{10}$ Marketing through television is one of the critical factors influencing food choices, eating preferences and eventually contributing to overweight and obesity among children and adolescents. ${ }^{8-10}$ This may be attributed to the inability of children and adolescents to comprehend the commercial context. Thus, are easily persuaded $^{7,11}$ to buy the product advertised on television.

Existing research using brief content analysis of food advertisements on Indian television has examined the prevalence of misleading advertisements. ${ }^{11-13}$ There is a paucity of research evidence on comprehensive content analysis of food advertisements broadcasted on television and how the advertisements differs by channel. The present study was conducted to fill the gap in literature, by undertaking detailed content analysis of Food advertisements broadcasted on the most popular national-level television channels among children and youth. The differences in the content of these advertisements: a) between channels (children vs youth); b) within the channel by day type (weekend and weekdays) and time were also explored.

\section{METHODS}

\section{STUDY DESIGN AND SAMPLING}

A cross-sectional study was conducted during SeptemberOctober in 2020. The topmost popular national television channels among children (2-14 years) and youth ( $>14$ years ) were selected based on the rating data obtained from the Broadcast Audience Research Council India (BARC), a television audience measurement service. ${ }^{14}$ In total, six channels, both free-to-air (E24) and paid channels (Nick, Sonic Nickelodeon, Pogo, Zing, and MTV), were included in the present study. Children's channels included in the present study were: Nick, Sonic Nickelodeon, and Pogo, whereas youth channels were, E24, Zing, and MTV. The study only analyzed secondary data and does not involve any human subjects, therefore, an informed consent procedure was not required.

\section{DATA COLLECTION}

The data was collected by recording programs on the six selected channels for three consecutive weeks in September 2020. In three weeks, weekdays were randomly selected by a lottery method and all weekends were considered for both children's and youth channels. In alignment with other Indian ${ }^{13}$ and international research, ${ }^{15}$ hours selected for recording in our study for all selected channels were: $4: 00 \mathrm{pm}$ to $10: 00 \mathrm{pm}$ on both weekdays and weekends with additional hours (10:00am-2:00pm) on weekends to understand the variability in advertisements broadcasted on these television channels.

\section{INSTRUMENT AND MEASURES}

The coding sheet was developed by adapting existing validated tools ${ }^{16,17}$ and previous brief content analysis research conducted in India ${ }^{13}$ and other countries. ${ }^{7,13,18}$ All recorded advertisements on selected channels were independently coded by two authors (HM and SD) to ensure consistency and avoid discrepancies while coding the advertisements. Any coding disagreement between the two researchers was resolved through a discussion with other senior authors (SB and DB) involved in this research. A pilot exercise was also performed by coding recorded advertisements $(n=75)$ to ensure consistency in entering the data by $\mathrm{HM}$ and SD.

As per coding guidelines, the advertised Foods on these channels were classified into four main categories: only food advertisements, only beverage advertisements, food + beverage advertisements, and food and beverage related advertisements. The pre-packaged food and beverage shown in the advertisement were further categorized as healthy or HFSS, using World Health Organization's (WHO) South East Asian Region (SEAR) Nutrient Profile Model, based on thresholds for fat, salt, and sugar. ${ }^{19}$ Additionally, Codex guidelines for the use of Nutrition and Health claims (CAC/ GL 23-1997) were used, providing details of nutrient health claims and the defined value for each claim. ${ }^{20}$ These guidelines helped determine whether the claims shown in advertisements were consistent with the information on the label. The labels of food products were procured and checked by two authors (HM and SD) independently for each nutrient to identify any misleading claims. SB and DB further verified these claims by randomly checking the advertisements ( $\mathrm{n}=5 \%$ of Food advertisements).

\section{DATA ANALYSIS}

We assessed the frequency of advertisements, type of advertisements, categorization of advertisements, brand benefits, selling point claims, and endorsement strategies used. All data were analyzed to understand the content of Food advertisements and differences between channels (children and youth channels) and within these channels by day and time. The data were analyzed using Stata version 13.0 (StataCorp, College Station, Texas, USA). ${ }^{21}$ For categorical data, Pearson test, and Fisher's exact test and for continuous data independent t-test was used. $p$-value less than or equal to 0.05 was considered statistically significant.

\section{RESULTS}

The total duration of programs observed was 168 hours, over six weekdays and six weekends on three children's and 
three youth channels. During these hours, a total of 5569 advertisements (Food advertisement:1735; Non-food advertisement:3834) were seen. A higher proportion of advertisements were seen on the children's channel (54.4\%) than on the youth channel (45.6\%) (Table 1).

\section{TYPE AND FREQUENCY OF ADVERTISEMENTS}

Advertisements seen on these channels (children's and youth) were broadly categorized under two categories i.e. Food advertisements and Non-food advertisements. The Food advertisements were further categorized into food only (candy, chips, chocolates, etc.); beverage only (juices, fizzy sweetened drinks, etc.); food + beverage (pizza and a fizzy sweetened beverage together); and food and beverage related advertisements (food and grocery delivery services, food outlets etc.).

The total advertisements broadcasted on children's and youth channels were 3026 and 2543, respectively. The Food advertisements aired were significantly higher on children's channels than youth channels ( $38 \%$ vs $23 \%, p<0.001)$. By day type, no statistically significant difference was seen for Food advertisements shown on children (weekday: 37.4\% vs weekend: $38.5 \%, p=0.553$ ) and youth channels (weekday: $23.6 \%$ vs weekend: $22.5 \%, p=0.513$ ) (Table 1 ).

More than one-fifth of Food advertisements were advertised between $8 \mathrm{pm}-9 \mathrm{pm}$ on weekdays on both children and youth channels (22.1\%). On weekends, the maximum Food advertisements were broadcasted in the evening between 4 pm-5 pm on children's channels (18.8\%), and $7 \mathrm{pm}-8 \mathrm{pm}$ (15.9\%) on youth channels (Figure 1).

\section{CLASSIFICATION OF FOOD ADVERTISEMENTS}

With further classification of Food advertisements to: 1) only food; 2) only beverage; 3) food + beverage and; 4) food and beverage related advertisements, analysis showed that on children's channels, food $(P<0.001)$ and food and beverage related advertisements $(P<0.001)$ were seen more compared to youth channels. In contrast, beverages advertisements were seen more on youth channels $(P<0.001)$. Within the children's and youth channel, no significant difference was seen for any of these categories by weekend or weekday (Table 2).

Of the food advertisements on the children's channel, almost one-third of advertisements were of candy (32.5\%). More than half of the advertisements (69.7\%) in beverage category were of food supplements on children's channels. In contrast, very few food and beverage related advertisements were seen on both channels and it was mainly the pizza outlet advertisements that was seen. Within the children's channels few foods were shown significantly more on weekdays (noodles, $\mathrm{p}=0.010$ ) others on weekends (biscuits, $P=0.013$ ) (Table 3).

Similarly, on the youth channel, the most common advertisement was for candy (32.9\%) within food advertisements. Of the beverage advertisements, one-third of the advertisements were for food supplements (38.4\%). Similar to children's channels, it was seen that few food and beverage advertisements were shown more on weekdays (noodles, $\mathrm{p}=0.003$; food supplements, $P=0.002$ ) other on weekends

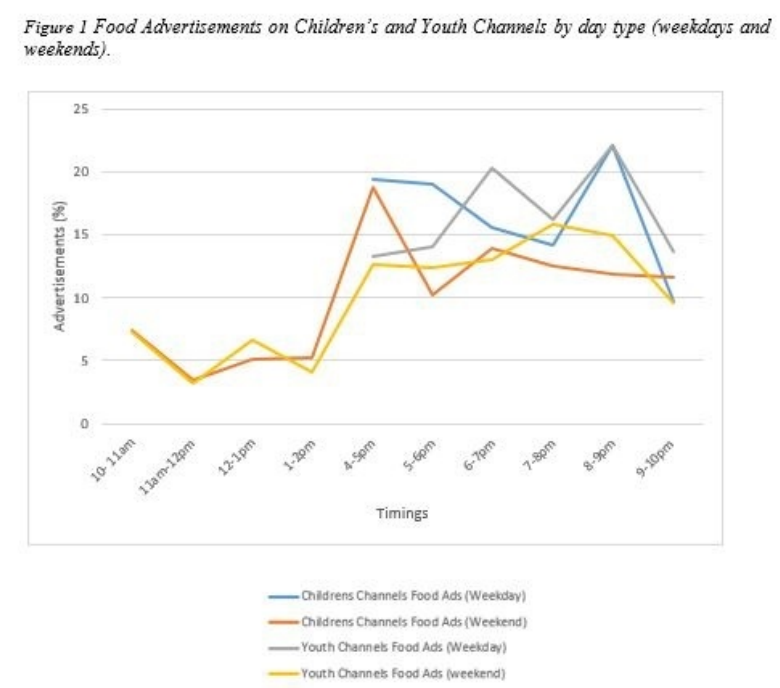

Figure 1. Food Advertisements on Children's and Youth Channels by day type (weekdays and weekends)

(tea/coffee, $P=0.012$; fizzy sweetened beverages, $P<0.001$ ) (Table 3).

\section{CATEGORIZATION OF FOOD ADVERTISEMENTS AS HEALTHY AND HFSS}

Food advertisements were categorized as healthy and HFSS using the WHO's SEAR Nutrient Profile Model based on sodium, fat, and sugar threshold values. ${ }^{19}$ Most advertisements broadcasted on the selected channels were HFSS (88.6\%), and a few were healthy (11.4\%). More HFSS advertisements were on children's channel (95.9\%) compared to $76.1 \%$ on youth channel $(P<0.001)$. Among children's channels, it was evident that HFSS foods were advertised more on weekends compared to weekdays $(P=0.006)$, but on the youth channels this difference was not significant $(p=0.089)$ (Table 4).

Within HFSS foods, foods high in sugar were seen more on children's (55.2\%) than youth channels (41.5\%) $(P<0.001)$. By day type, high sugar foods were advertised on youth channels on the weekends $(P=0.006)$ and high in fat and sodium on weekdays $(P=0.045)$. Whereas on children's channels, difference was only seen for HFSS as were advertised more on the weekend $(P<0.001)$ (Table 4$)$.

Since the majority of advertisements were HFSS, we attempted to understand the variation of these advertisements broadcasted by timings. On children's channels, maximum proportion of advertisements for foods high in sugar and sodium peaked between $8 \mathrm{pm}-9 \mathrm{pm}$ on weekdays (Figure 2) and 5pm-6pm on weekends (Figure 3). Whereas, on the youth channels, the peak was observed for foods high in fat and sugar between $6 \mathrm{pm}$ and $7 \mathrm{pm}$ on weekdays (Figure 4), and foods high in sugar between $9 \mathrm{pm}$ and $10 \mathrm{pm}$ on weekends (igure 5).

\section{BRAND BENEFITS OF ADVERTISEMENTS}

Companies claimed various benefits to attract users, and 
these benefits were found to be different for children and youth. The most common brand benefit on children's channels were sensory-based characteristics (40.9\%) i.e. taste, texture, aroma, etc. followed by suggestive users for children or family (25.8\%). While on youth channels, the most prevalent brand benefit claimed was use of emotive claims (31.6\%) i.e., feelings of fun, popularity, etc. followed by sensory characteristics (23.1\%) and price (22.8\%).

\section{SELLING POINT CLAIM}

Companies were using different selling claims; approximately one-fourth of Food advertisements on youth channels $(23.7 \%)$ and $13.3 \%$ on children's channels had no selling claims $(P<0.001)$. The taste of an advertised product (28.3\%) was claimed as one of the selling points, significantly more on children's channel than youth channel $(P<0.001)$. Whereas, on youth channels, general health claims (22.9\%) were most common and were significantly higher compared to children's channels $(P<0.001)$ (Table 5$)$.

Concerning the nutrient content, which is also a selling point claims (Table 5), enhanced nutrients (increase in content is at least $30 \%$ compared to a similar product) was the highest-selling claim seen on children's channels (39.2\%), followed by protein enriched (36.0\%). Similarly, the source of vitamins and minerals was claimed most frequently (77.8\%), followed by rich dietary fiber $(16.7 \%)$ on the youth channels. None of these claims were found to be misleading when verified through the food labels.

\section{ENDORSEMENT STRATEGIES}

On the children's channels, the most common endorsement strategy used was the presence of children in almost half of the advertisements (49.0\%), and on youth channels, endorsement by a non-sports celebrity (32.6\%).

\section{DISCUSSION}

This is one of the first studies that have undertaken the detailed content analysis of food advertisements (i.e. only food, only beverage, food + beverage, and food and beverage related) broadcasted on most popular channels among children (2-14 years) and youth (>14 years) on weekdays and weekends.

The study findings showed that $38 \%$ and $23 \%$ of advertisements were of food on children's and youth channels, respectively. Similar to our findings, a study conducted in India reported that $46 \%$ of advertisements were for food on television programs targeting children, ${ }^{22}$ whereas a study conducted in Argentina showed a lower (20\%) proportion of food and beverage advertisements. ${ }^{23}$

Our study findings showed no difference in weekends and weekdays for food and non-food advertisements. This could be attributed as the study data was collected when schools were closed due to COVID-19 and children were confined to their homes for both academic and leisure activities. ${ }^{24}$ Thus, companies might have considered the weekday and weekend as an equal opportunistic time to advertise their products to attract the young population. Similarly, in UK, the Advertising Standards Authority re-

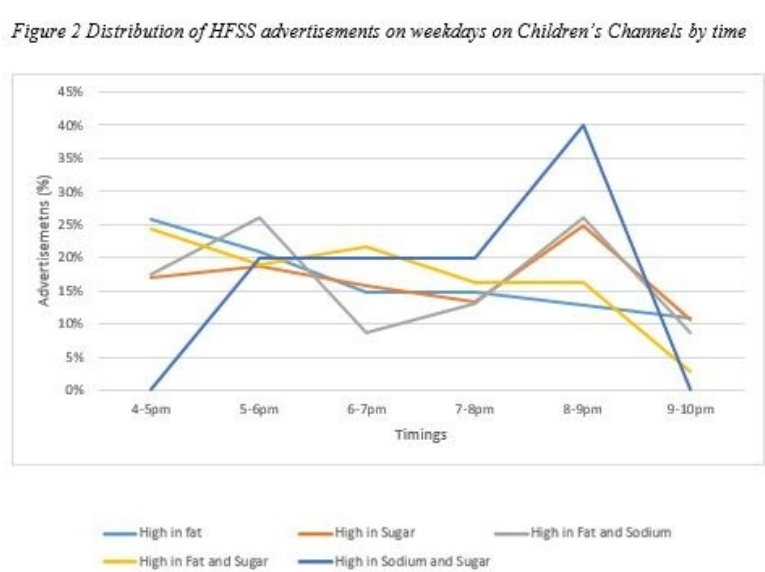

Figure 2. Distribution of HFSS advertisements on weekdays on Children's Channels by time

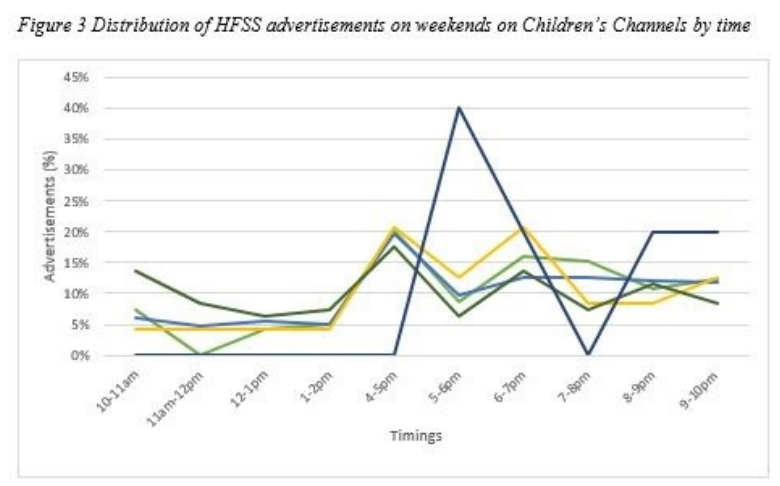

Figure 3. Distribution of HFSS advertisements on weekends on Children's Channels by time

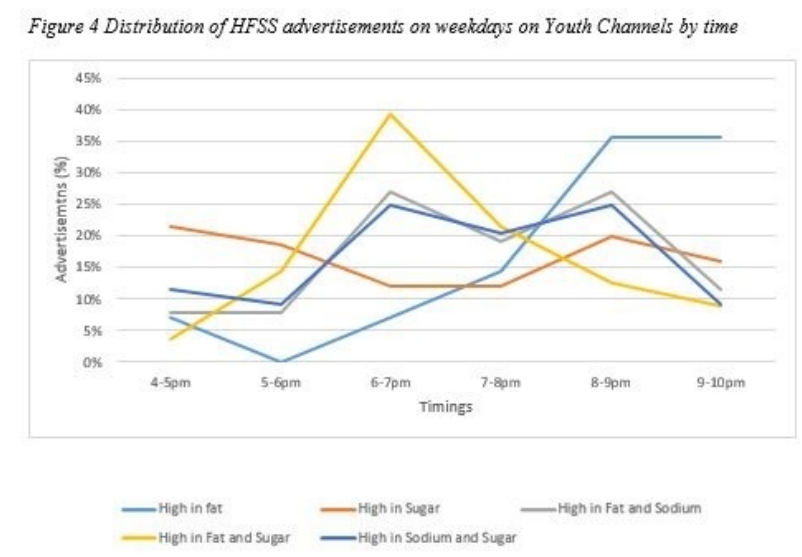

Figure 4. Distribution of HFSS advertisements on weekdays on Youth Channels by time 
ported an increase in exposure to advertisements (soft drinks, sports drinks, confectioneries and snacks) among both children and adults during the COVID-19 lockdown, as compared to 2019.25

In our study, the Food advertisements were broadcasted on both the children's and youth channels during 8pm-9pm on weekdays. On weekends, the maximum number of Food advertisements were seen between $4 \mathrm{pm}-5 \mathrm{pm}$ on the children's channels and during 7pm- $8 \mathrm{pm}$ on the youth channels. Secondary data from BARC also supports our findings and shows that on both weekdays and weekends, the peak viewership on youth channels is between 8:30pm-9:00pm. ${ }^{26}$

In our study, a total of $88.6 \%$ of advertisements were for HFSS foods. These HFSS advertisements can create and promote an obesogenic environment that can strongly influence children's buying behavior. ${ }^{27}$ Similar findings from studies conducted in India 12,28 and Southeast Asian countries $^{29}$ highlighted that majority (90-95\%) of advertisements broadcasted on television channels targeting children and youth were of HFSS foods. The most frequently advertised products on children's (32.5\%) and youth (32.9\%) channels in our study were candies. These findings are similar to other studies conducted in India ${ }^{22,28}$ and other countries like Lebanon, ${ }^{30}$ Sri Lanka, ${ }^{29}$ and the United States. ${ }^{18}$

Using children in advertising or any other communication type for brand building is likely to affect purchase intentions. ${ }^{31}$ In our study, the most common endorsement strategy was children's presence in almost half of the advertisements (49\%) on children's channels. Similar findings were reported from a study conducted in Sri Lanka. ${ }^{29}$ Another study depicting global representation reported that out of 16 countries, 30\% of food and beverage advertisements contained promotional characters like company - owned media characters, brand - equity mascots, third - party licensed characters, entertainment, or sports celebrities. ${ }^{32}$ Contrary to this, our study showed the presence of cartoons in only $7.7 \%$ of advertisements on children's channels. The use of cartoon characters, fantasy world, and excitement in advertisements is strongly correlated with purchase of those products among children. ${ }^{33}$ In light of mounting evidence, few countries have taken initiatives by formulating policy or pledges by the industry to restrict the use of brand mascots, to promote HFSS foods. ${ }^{34}$ The Chilean government introduced a food labeling law in 2016 with a measure for the removal of licensed and brand characters to promote HFSS foods. ${ }^{34}$

Marketing gimmicks like offers, health benefits, and price reduction have positively impacted a brand. ${ }^{13}$ In our study, sensory-based characteristics such as taste, texture, and aroma were the most used brand benefits claimed (40.9\%) by the advertisements on children's channels. A review conducted in 2008 also highlighted hedonistic characteristics like taste and sensory appeal are used to promote children's food products. ${ }^{35}$ This is because taste and smell provoke the advertised food consumption pattern rather than similar products that are not heavily advertised, thus making a good appeal to target children. ${ }^{36}$ A study conducted in the United States stated that adolescents could be persuaded by the emotive messages of advertising, which

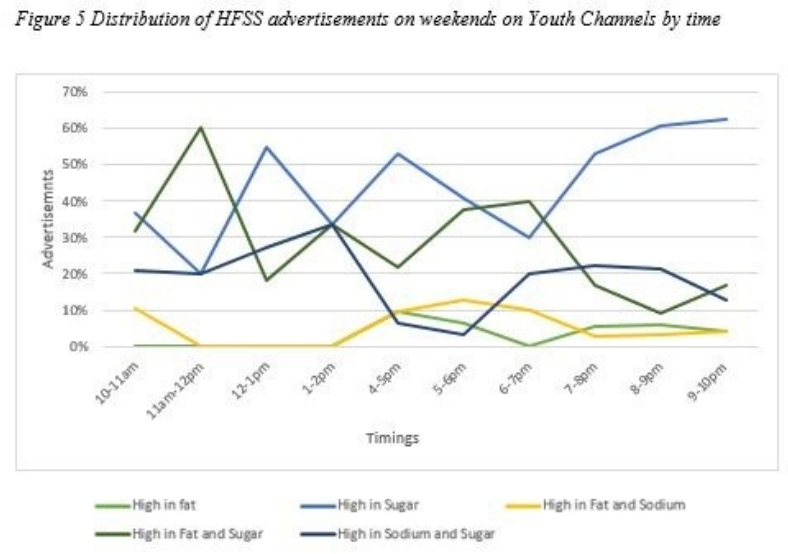

Figure 5. Distribution of HFSS advertisements on weekends on Youth Channels by time

play into their developmental concerns related to appearance, self-identity, belongingness, and sexuality. ${ }^{37}$ Our study similarly found emotive claims $(31.6 \%)$ to be a prominent marketing gimmick on the youth channels. This shows that companies invest in research to develop their strategy to cash in on the development and emotional needs of the customer.

In India the Consumer Protection Act, 2019 stipulates punishment for false or misleading advertisements by any manufacturer. ${ }^{38}$ Additionally, the program and advertising codes prescribed under the Cable Television Network Rules, $1994^{39}$ state that 'No advertisement which endangers the safety of children or creates in them any interest in unhealthy practices or shows them begging or in an undignified or indecent manner shall not be carried in the cable service.' The Food Safety and Standards Act, 2006 has clause 53 in section 56 that clearly states that any person who publishes or is a party to the publication of an advertisement which, a) falsely describes any food or; b) is likely to mislead as to the nature or substance or quality of any food or gives a false guarantee, shall be liable to a penalty which may extend to ten lakh rupees. ${ }^{17}$ However, no clear reference to the marketing of HFSS foods to children or exact time regulations were made in these acts. A self-regulatory voluntary organization, the Advertising Standards Council of India (ASCI) can also pressurize advertisers and companies to withdraw objectionable advertisements. ${ }^{40}$ Despite these initiatives in India, there are advertisements of HFSS foods shown on television, that appeal to children. Hence, similar to other countries, ${ }^{41}$ there is a need for regulatory guidelines for creating a better food advertising environment by monitoring and controlling television food advertisements. There is need to develop national databases for tracking all broadcasts to periodically inform the enforcement of food advertisements targeting children and youth in India.

This study is one of the first of its kind in India, which comprehensively analyzed the content of food advertisements between and within channels in the Indian context. Therefore, it can act as a foundation for conducting more region-specific studies to assess the impact of the obeso- 
genic environment among children and youth. One of the limitations of our study is that the study only analyzed the content on national children's and youth channels, thus the findings of this study may not be generalizable. We also did not conceptualize any confounding variables for the current research question, and therefore a regression model was not applied. Additionally, other modes of exposure to advertisements including advertising on streaming services, internet, social media, etc. were not explored. 
Table 1. Distribution of advertisements based on channel type and day type

\begin{tabular}{|c|c|c|c|c|c|c|c|c|c|}
\hline & \multicolumn{3}{|c|}{$\begin{array}{l}\text { Overall } \\
N \\
(\%)\end{array}$} & \multicolumn{3}{|c|}{$\begin{array}{c}\text { Children's Channels } \\
\text { N } \\
(\%)\end{array}$} & \multicolumn{3}{|c|}{$\begin{array}{c}\text { Youth Channels } \\
N \\
(\%)\end{array}$} \\
\hline & Children's Channels & $\begin{array}{c}\text { Youth } \\
\text { Channels }\end{array}$ & $\mathrm{p}$-value & Weekday & Weekend & $p$-value & Weekday & Weekend & $\mathrm{p}$-value \\
\hline Total advertisements & $\begin{array}{l}3026 \\
(54.4)\end{array}$ & $\begin{array}{l}2543 \\
(45.6)\end{array}$ & - & $\begin{array}{l}1339 \\
(44.3)\end{array}$ & $\begin{array}{l}1687 \\
(55.7)\end{array}$ & & $\begin{array}{l}1148 \\
(45.1)\end{array}$ & $\begin{array}{l}1395 \\
(54.9)\end{array}$ & - \\
\hline Food advertisements & $\begin{array}{l}1150 \\
(38.0)\end{array}$ & $\begin{array}{c}585 \\
(23.0)\end{array}$ & \multirow{2}{*}{$<0.001$} & $\begin{array}{c}501 \\
(37.4)\end{array}$ & $\begin{array}{c}649 \\
(38.5)\end{array}$ & \multirow{2}{*}{0.553} & $\begin{array}{c}271 \\
(23.6)\end{array}$ & $\begin{array}{c}314 \\
(22.5)\end{array}$ & \multirow{2}{*}{0.513} \\
\hline Non-Food advertisements & $\begin{array}{l}1876 \\
(62.0)\end{array}$ & $\begin{array}{l}1958 \\
(77.0)\end{array}$ & & $\begin{array}{c}838 \\
(62.6)\end{array}$ & $\begin{array}{l}1038 \\
(61.5)\end{array}$ & & $\begin{array}{c}877 \\
(76.4)\end{array}$ & $\begin{array}{l}1081 \\
(77.5)\end{array}$ & \\
\hline
\end{tabular}

Table 2. Distribution of advertisements of Food categories by channels and day type

\begin{tabular}{|c|c|c|c|c|c|c|c|c|c|}
\hline \multirow[b]{2}{*}{ Food Category } & \multicolumn{3}{|c|}{ Overall $(\mathrm{N}=5569)$} & \multicolumn{3}{|c|}{ Children's Channels ( $N=3026$ ) } & \multicolumn{3}{|c|}{ Youth Channels ( $\mathrm{N}=2543$ ) } \\
\hline & $\begin{array}{l}\text { Children's } \\
\text { channel } \\
\text { (n=1150) }\end{array}$ & $\begin{array}{l}\text { Youth } \\
\text { Channels } \\
(n=585)\end{array}$ & p-value & $\begin{array}{l}\text { Weekday } \\
(n=501)\end{array}$ & $\begin{array}{l}\text { Weekend } \\
(\mathrm{n}=649)\end{array}$ & p-value & $\begin{array}{l}\text { Weekday } \\
(n=271)\end{array}$ & $\begin{array}{l}\text { Weekend } \\
(n=314)\end{array}$ & $\mathrm{p}$-value \\
\hline & $\mathrm{N}(\%)$ & $\mathrm{N}(\%)$ & & $\mathrm{N}(\%)$ & $\mathrm{N}(\%)$ & & $\mathrm{N}(\%)$ & $\mathrm{N}(\%)$ & \\
\hline Food advertisements & $\begin{array}{c}799 \\
(69.5)\end{array}$ & $\begin{array}{c}345 \\
(59.0)\end{array}$ & $<0.001$ & $\begin{array}{c}356 \\
(71.1)\end{array}$ & $\begin{array}{c}443 \\
(68.3)\end{array}$ & 0.839 & $\begin{array}{c}171 \\
(63.1)\end{array}$ & $\begin{array}{c}174 \\
(55.4)\end{array}$ & 0.076 \\
\hline Beverage advertisements & $\begin{array}{c}297 \\
(25.8)\end{array}$ & $\begin{array}{c}237 \\
(40.5)\end{array}$ & $<0.001$ & $\begin{array}{c}118 \\
(23.5)\end{array}$ & $\begin{array}{c}179 \\
(27.6)\end{array}$ & 0.099 & $\begin{array}{c}100 \\
(36.9)\end{array}$ & $\begin{array}{c}137 \\
(43.6)\end{array}$ & 0.338 \\
\hline Food + beverage advertisements & $\begin{array}{c}0 \\
(0.0)\end{array}$ & $\begin{array}{c}0 \\
(0.0)\end{array}$ & - & $\begin{array}{c}0 \\
(0.0)\end{array}$ & $\begin{array}{c}0 \\
(0.0)\end{array}$ & - & $\begin{array}{c}0 \\
(0.0)\end{array}$ & $\begin{array}{c}0 \\
(0.0)\end{array}$ & - \\
\hline Food and beverage related advertisements & $\begin{array}{c}54 \\
(4.7)\end{array}$ & $\begin{array}{c}3 \\
(0.5)\end{array}$ & $<0.001$ & $\begin{array}{c}27 \\
(5.4)\end{array}$ & $\begin{array}{c}27 \\
(4.2)\end{array}$ & 0.391 & $\begin{array}{c}0 \\
(0.0)\end{array}$ & $\begin{array}{c}3 \\
(1.0)\end{array}$ & 0.116 \\
\hline
\end{tabular}


Table 3. Foods and beverage items under Food categories in children's and youth channel by day type

\begin{tabular}{|c|c|c|c|c|c|c|c|c|}
\hline \multirow{2}{*}{$\begin{array}{l}\text { Advertisement category } \\
\text { Food Advertisements }\end{array}$} & \multicolumn{2}{|c|}{$\begin{array}{c}\text { Overall }(N=1735) \\
N(\%)\end{array}$} & \multicolumn{3}{|c|}{$\begin{array}{l}\text { Children's Channels (N=1150) } \\
\text { N (\%) }\end{array}$} & \multicolumn{3}{|c|}{$\begin{array}{c}\text { Youth Channels ( } N=585) \\
N(\%)\end{array}$} \\
\hline & $\begin{array}{l}\text { Children's Channels } \\
\quad(n=799)\end{array}$ & $\begin{array}{l}\text { Youth Channels } \\
(n=345)\end{array}$ & $\begin{array}{l}\text { Weekday } \\
(n=356)\end{array}$ & $\begin{array}{l}\text { Weekend } \\
(n=443)\end{array}$ & p-value & $\begin{array}{l}\text { Weekday } \\
(n=171)\end{array}$ & $\begin{array}{l}\text { Weekend } \\
(n=174)\end{array}$ & $\mathrm{p}$-value \\
\hline Candies & $\begin{array}{c}260 \\
(32.5)\end{array}$ & $\begin{array}{c}113 \\
(32.9)\end{array}$ & $\begin{array}{c}119 \\
(33.3)\end{array}$ & $\begin{array}{c}121 \\
(31.8)\end{array}$ & 0.342 & $\begin{array}{c}51 \\
(29.8)\end{array}$ & $\begin{array}{c}62 \\
(35.6)\end{array}$ & 0.266 \\
\hline Dairy products (ice-creams) & $\begin{array}{c}73 \\
(9.1)\end{array}$ & $\begin{array}{c}0 \\
(0.0)\end{array}$ & $\begin{array}{c}27 \\
(7.6)\end{array}$ & $\begin{array}{c}46 \\
(10.4)\end{array}$ & 0.259 & $\begin{array}{c}0 \\
(0.0)\end{array}$ & $\begin{array}{c}0 \\
(0.0)\end{array}$ & - \\
\hline Breakfast cereals & $\begin{array}{c}113 \\
(14.1)\end{array}$ & $\begin{array}{c}12 \\
(3.5)\end{array}$ & $\begin{array}{c}54 \\
(15.2)\end{array}$ & $\begin{array}{c}59 \\
(13.3)\end{array}$ & 0.303 & $\begin{array}{c}5 \\
(2.9)\end{array}$ & $\begin{array}{c}7 \\
(4.0)\end{array}$ & 0.584 \\
\hline Chips & $\begin{array}{c}103 \\
(12.9)\end{array}$ & $\begin{array}{c}34 \\
(9.9)\end{array}$ & $\begin{array}{c}47 \\
(13.2)\end{array}$ & $\begin{array}{c}56 \\
(12.6)\end{array}$ & 0.609 & $\begin{array}{c}18 \\
(10.5)\end{array}$ & $\begin{array}{c}16 \\
(9.2)\end{array}$ & 0.666 \\
\hline Biscuits & $\begin{array}{c}69 \\
(8.6)\end{array}$ & $\begin{array}{c}3 \\
(0.9)\end{array}$ & $\begin{array}{c}20 \\
(5.6)\end{array}$ & $\begin{array}{c}49 \\
(11.1)\end{array}$ & 0.013 & $\begin{array}{c}0 \\
(0.0)\end{array}$ & $\begin{array}{c}3 \\
(1.7)\end{array}$ & 0.086 \\
\hline Noodles & $\begin{array}{c}55 \\
(6.9)\end{array}$ & $\begin{array}{l}15 \\
(4.4)\end{array}$ & $\begin{array}{c}33 \\
(9.3)\end{array}$ & $\begin{array}{c}22 \\
(5.0)\end{array}$ & 0.010 & $\begin{array}{c}13 \\
(7.6)\end{array}$ & $\begin{array}{c}2 \\
(1.2)\end{array}$ & 0.003 \\
\hline Oils & $\begin{array}{c}40 \\
(5.0)\end{array}$ & $\begin{array}{c}0 \\
(0.0)\end{array}$ & $\begin{array}{c}18 \\
(5.1)\end{array}$ & $\begin{array}{c}22 \\
(5.0)\end{array}$ & 0.822 & $\begin{array}{c}0 \\
(0.0)\end{array}$ & $\begin{array}{c}0 \\
(0.0)\end{array}$ & - \\
\hline Chocolates & $\begin{array}{c}30 \\
(3.7)\end{array}$ & $\begin{array}{c}106 \\
(30.7)\end{array}$ & $\begin{array}{l}16 \\
(4.5)\end{array}$ & $\begin{array}{c}14 \\
(3.2)\end{array}$ & 0.259 & $\begin{array}{c}56 \\
(32.7)\end{array}$ & $\begin{array}{c}50 \\
(28.7)\end{array}$ & 0.399 \\
\hline Popcorns & $\begin{array}{c}24 \\
(3.0)\end{array}$ & $\begin{array}{c}0 \\
(0.0)\end{array}$ & $\begin{array}{c}12 \\
(3.4)\end{array}$ & $\begin{array}{c}12 \\
(2.7)\end{array}$ & 0.569 & $\begin{array}{c}0 \\
(0.0)\end{array}$ & $\begin{array}{c}0 \\
(0.0)\end{array}$ & - \\
\hline Spices & $\begin{array}{c}19 \\
(2.4)\end{array}$ & $\begin{array}{c}0 \\
(0.0)\end{array}$ & $\begin{array}{c}7 \\
(2.0)\end{array}$ & $\begin{array}{c}12 \\
(2.7)\end{array}$ & 0.568 & $\begin{array}{c}0 \\
(0.0)\end{array}$ & $\begin{array}{c}0 \\
(0.0)\end{array}$ & - \\
\hline Cakes & $\begin{array}{c}13 \\
(1.6)\end{array}$ & $\begin{array}{c}0 \\
(0.0)\end{array}$ & $\begin{array}{c}3 \\
(0.8)\end{array}$ & $\begin{array}{c}10 \\
(2.3)\end{array}$ & 0.139 & $\begin{array}{c}0 \\
(0.0)\end{array}$ & $\begin{array}{c}0 \\
(0.0)\end{array}$ & - \\
\hline Sauces & $\begin{array}{c}0 \\
(0.0)\end{array}$ & $\begin{array}{c}42 \\
(12.2)\end{array}$ & $\begin{array}{c}0 \\
(0.0)\end{array}$ & $\begin{array}{c}0 \\
(0.0)\end{array}$ & - & $\begin{array}{c}19 \\
(11.1)\end{array}$ & $\begin{array}{c}23 \\
(13.2)\end{array}$ & 0.563 \\
\hline Fruit based products (Jams and Jellies) & $\begin{array}{c}0 \\
(0.0)\end{array}$ & $\begin{array}{c}18 \\
(5.2)\end{array}$ & $\begin{array}{c}0 \\
(0.0)\end{array}$ & $\begin{array}{c}0 \\
(0.0)\end{array}$ & - & $\begin{array}{c}9 \\
(5.3)\end{array}$ & $\begin{array}{c}9 \\
(5.2)\end{array}$ & 0.960 \\
\hline Dates & $\begin{array}{c}0 \\
(0.0)\end{array}$ & $\begin{array}{c}2 \\
(0.6)\end{array}$ & $\begin{array}{c}0 \\
(0.0)\end{array}$ & $\begin{array}{c}0 \\
(0.0)\end{array}$ & - & $\begin{array}{c}0 \\
(0.0)\end{array}$ & $\begin{array}{c}2 \\
(1.2)\end{array}$ & 0.505 \\
\hline Beverage Advertisements & $\begin{array}{l}\text { Children's Channels } \\
\quad(n=297)\end{array}$ & $\begin{array}{c}\text { Youth Channels } \\
(n=237)\end{array}$ & $\begin{array}{l}\text { Weekday } \\
(n=118)\end{array}$ & $\begin{array}{l}\text { Weekend } \\
(n=179)\end{array}$ & $p$-value & $\begin{array}{l}\text { Weekday } \\
(n=100)\end{array}$ & $\begin{array}{c}\text { Weekend } \\
(n=137)\end{array}$ & $\mathrm{p}$-value \\
\hline Food supplements & 207 & 91 & 80 & 127 & 0.783 & 50 & 41 & 0.002 \\
\hline
\end{tabular}




\begin{tabular}{|c|c|c|c|c|c|c|c|c|}
\hline & $(69.7)$ & $(38.4)$ & $(67.8)$ & (71.0) & & $(50.0)$ & $(29.9)$ & \\
\hline Dairy products (Milkshakes) & $\begin{array}{c}61 \\
(20.6)\end{array}$ & $\begin{array}{c}0 \\
(0.0)\end{array}$ & $\begin{array}{c}26 \\
(22.0)\end{array}$ & $\begin{array}{c}35 \\
(19.6)\end{array}$ & 0.582 & $\begin{array}{c}0 \\
(0.0)\end{array}$ & $\begin{array}{c}0 \\
(0.0)\end{array}$ & - \\
\hline Health/ energy drinks & $\begin{array}{c}25 \\
(8.4)\end{array}$ & $\begin{array}{c}0 \\
(0.0)\end{array}$ & $\begin{array}{c}12 \\
(10.2)\end{array}$ & $\begin{array}{c}13 \\
(7.3)\end{array}$ & - & $\begin{array}{c}0 \\
(0.0)\end{array}$ & $\begin{array}{c}0 \\
(0.0)\end{array}$ & - \\
\hline Tea/ coffee & $\begin{array}{c}0 \\
(0.0)\end{array}$ & $\begin{array}{c}52 \\
(21.9)\end{array}$ & $\begin{array}{c}0 \\
(0.0)\end{array}$ & $\begin{array}{c}0 \\
(0.0)\end{array}$ & - & $\begin{array}{c}14 \\
(14.0)\end{array}$ & $\begin{array}{c}38 \\
(27.7)\end{array}$ & 0.012 \\
\hline Fizzy sweetened beverages & $\begin{array}{c}0 \\
(0.0)\end{array}$ & $\begin{array}{c}38 \\
(16.0)\end{array}$ & $\begin{array}{c}0 \\
(0.0)\end{array}$ & $\begin{array}{c}0 \\
(0.0)\end{array}$ & - & $\begin{array}{c}6 \\
(6.0)\end{array}$ & $\begin{array}{c}32 \\
(23.4)\end{array}$ & $<0.001$ \\
\hline Packaged fruit juices & $\begin{array}{c}0 \\
(0.0)\end{array}$ & $\begin{array}{c}29 \\
(12.2)\end{array}$ & $\begin{array}{c}0 \\
(0.0)\end{array}$ & $\begin{array}{c}0 \\
(0.0)\end{array}$ & - & $\begin{array}{c}17 \\
(17.0)\end{array}$ & $\begin{array}{c}12 \\
(8.8)\end{array}$ & 0.056 \\
\hline Soups & $\begin{array}{c}0 \\
(0.0)\end{array}$ & $\begin{array}{c}22 \\
(9.3)\end{array}$ & $\begin{array}{c}0 \\
(0.0)\end{array}$ & $\begin{array}{c}0 \\
(0.0)\end{array}$ & - & $\begin{array}{c}13 \\
(13.0)\end{array}$ & $\begin{array}{c}9 \\
(6.6)\end{array}$ & 0.092 \\
\hline Date Syrup & $\begin{array}{c}0 \\
(0.0)\end{array}$ & $\begin{array}{c}1 \\
(0.4)\end{array}$ & $\begin{array}{c}0 \\
(0.0)\end{array}$ & $\begin{array}{c}0 \\
(0.0)\end{array}$ & - & $\begin{array}{c}0 \\
(0.0)\end{array}$ & $\begin{array}{c}1 \\
(0.7)\end{array}$ & 0.392 \\
\hline Food and Beverage Related Advertisements & $\begin{array}{l}\text { Children's Channels } \\
\qquad(n=54)\end{array}$ & $\begin{array}{l}\text { Youth Channels } \\
\qquad(n=3)\end{array}$ & $\begin{array}{l}\text { Weekday } \\
(n=118)\end{array}$ & $\begin{array}{c}\text { Weekend } \\
(n=27)\end{array}$ & p-value & $\begin{array}{l}\text { Weekday } \\
(n=0)\end{array}$ & $\begin{array}{l}\text { Weekend } \\
(n=3)\end{array}$ & p-value \\
\hline Pizza & $\begin{array}{c}31 \\
(57.4)\end{array}$ & $\begin{array}{c}0 \\
(0.0)\end{array}$ & $\begin{array}{c}17 \\
(63.0)\end{array}$ & $\begin{array}{c}14 \\
(51.9)\end{array}$ & 0.409 & $\begin{array}{c}0 \\
(0.0)\end{array}$ & $\begin{array}{c}0 \\
(0.0)\end{array}$ & - \\
\hline Food delivery Service & $\begin{array}{c}0 \\
(0.0)\end{array}$ & $\begin{array}{c}3 \\
(100.0)\end{array}$ & $\begin{array}{c}0 \\
(0.0)\end{array}$ & $\begin{array}{c}0 \\
(0.0)\end{array}$ & - & $\begin{array}{c}0 \\
(0.0)\end{array}$ & $\begin{array}{c}3 \\
(0.0)\end{array}$ & - \\
\hline Online grocery shopping store & $\begin{array}{c}23 \\
(42.6)\end{array}$ & $\begin{array}{c}0 \\
(0.0)\end{array}$ & $\begin{array}{c}10 \\
(37.0)\end{array}$ & $\begin{array}{c}13 \\
(48.2)\end{array}$ & 0.409 & $\begin{array}{c}0 \\
(0.0)\end{array}$ & $\begin{array}{c}0 \\
(0.0)\end{array}$ & - \\
\hline
\end{tabular}


Table 4. Distribution of Healthy and HFSS foods* by channel and day type

\begin{tabular}{|c|c|c|c|c|c|c|c|c|c|}
\hline \multirow[t]{2}{*}{ Food Classification } & \multicolumn{3}{|c|}{ Overall } & \multicolumn{3}{|c|}{ Children's Channels } & \multicolumn{3}{|c|}{ Youth Channels } \\
\hline & $\begin{array}{l}\text { Children's Channels } \\
(n=1001)\end{array}$ & $\begin{array}{l}\text { Youth Channels } \\
\quad(n=582)\end{array}$ & p-value & $\begin{array}{l}\text { Weekday } \\
(n=426)\end{array}$ & $\begin{array}{l}\text { Weekend } \\
(n=574)\end{array}$ & $\mathrm{p}$-value & $\begin{array}{l}\text { Weekday } \\
(n=271)\end{array}$ & $\begin{array}{l}\text { Weekend } \\
(n=311)\end{array}$ & $\mathrm{p}$-value \\
\hline & $\mathrm{N}(\%)$ & $\mathrm{N}(\%)$ & & $\mathrm{N}(\%)$ & $\mathrm{N}(\%)$ & & $\mathrm{N}(\%)$ & $\mathrm{N}(\%)$ & \\
\hline Healthy Foods & $\begin{array}{c}41 \\
(4.1)\end{array}$ & $\begin{array}{c}139 \\
(23.9)\end{array}$ & \multirow{2}{*}{$<0.001$} & $\begin{array}{c}26 \\
(6.1)\end{array}$ & $\begin{array}{c}15 \\
(2.6)\end{array}$ & \multirow{2}{*}{0.006} & $\begin{array}{c}56 \\
(20.7)\end{array}$ & $\begin{array}{c}83 \\
(26.7)\end{array}$ & \multirow{2}{*}{0.089} \\
\hline Foods high in fat, salt and Sugar & $\begin{array}{c}960 \\
(95.9)\end{array}$ & $\begin{array}{c}443 \\
(76.1)\end{array}$ & & $\begin{array}{c}401 \\
(93.9)\end{array}$ & $\begin{array}{c}559 \\
(97.4)\end{array}$ & & $\begin{array}{c}215 \\
(79.4)\end{array}$ & $\begin{array}{c}228 \\
(73.3)\end{array}$ & \\
\hline High in fat & $\begin{array}{c}239 \\
(24.9)\end{array}$ & $\begin{array}{c}24 \\
(5.4)\end{array}$ & $<0.001$ & $\begin{array}{c}101 \\
(25.2)\end{array}$ & $\begin{array}{c}138 \\
(24.7)\end{array}$ & 0.860 & $\begin{array}{c}14 \\
(6.5)\end{array}$ & $\begin{array}{l}10 \\
(4.4)\end{array}$ & 0.323 \\
\hline High in sodium & $\begin{array}{c}0 \\
(0.0)\end{array}$ & $\begin{array}{c}0 \\
(0.0)\end{array}$ & - & $\begin{array}{c}0 \\
(0.0)\end{array}$ & $\begin{array}{c}0 \\
(0.0)\end{array}$ & - & $\begin{array}{c}0 \\
(0.0)\end{array}$ & $\begin{array}{c}0 \\
(0.0)\end{array}$ & - \\
\hline High in sugar & $\begin{array}{c}530 \\
(55.2)\end{array}$ & $\begin{array}{c}184 \\
(41.5)\end{array}$ & $<0.001$ & $\begin{array}{c}235 \\
(58.6)\end{array}$ & $\begin{array}{c}295 \\
(52.8)\end{array}$ & 0.073 & $\begin{array}{c}75 \\
(34.9)\end{array}$ & $\begin{array}{c}109 \\
(47.8)\end{array}$ & 0.006 \\
\hline High in fat, sodium and sugar & $\begin{array}{c}0 \\
(0.0)\end{array}$ & $\begin{array}{c}0 \\
(0.0)\end{array}$ & - & $\begin{array}{c}0 \\
(0.0)\end{array}$ & $\begin{array}{c}0 \\
(0.0)\end{array}$ & - & $\begin{array}{c}0 \\
(0.0)\end{array}$ & $\begin{array}{c}0 \\
(0.0)\end{array}$ & - \\
\hline High in fat and sodium & $\begin{array}{c}47 \\
(4.9)\end{array}$ & $\begin{array}{c}41 \\
(9.3)\end{array}$ & 0.002 & $\begin{array}{c}23 \\
(5.7)\end{array}$ & $\begin{array}{c}24 \\
(4.3)\end{array}$ & 0.307 & $\begin{array}{c}26 \\
(12.1)\end{array}$ & $\begin{array}{l}15 \\
(6.6)\end{array}$ & 0.045 \\
\hline High in fat and sugar & $\begin{array}{c}134 \\
(14.0)\end{array}$ & $\begin{array}{c}113 \\
(25.5)\end{array}$ & $<0.001$ & $\begin{array}{l}37 \\
(9.2)\end{array}$ & $\begin{array}{c}96 \\
(17.2)\end{array}$ & $<0.001$ & $\begin{array}{c}56 \\
(26.0)\end{array}$ & $\begin{array}{c}57 \\
(25.0)\end{array}$ & 0.801 \\
\hline High in sodium and sugar & $\begin{array}{c}10 \\
(1.0)\end{array}$ & $\begin{array}{c}81 \\
(18.3)\end{array}$ & $<0.001$ & $\begin{array}{c}5 \\
(1.2)\end{array}$ & $\begin{array}{c}5 \\
(0.9)\end{array}$ & 0.596 & $\begin{array}{c}44 \\
(20.5)\end{array}$ & $\begin{array}{c}37 \\
(16.2)\end{array}$ & 0.249 \\
\hline
\end{tabular}

* Of the 1735 food and beverage advertisements, the food labels were only available for 1583 advertisements, across both children and youth channels 
Table 5. Comparison of selling point claims by channel

\begin{tabular}{|c|c|c|c|}
\hline Selling point claims & $\begin{array}{l}\text { Children's channels } \\
(\mathrm{N}=1648) \dagger \\
N(\%)\end{array}$ & $\begin{array}{l}\begin{array}{l}\text { Youth } \\
\text { channels } \\
(\mathrm{N}=765) \dagger \\
\mathrm{N}(\%)\end{array}\end{array}$ & $\begin{array}{l}\mathrm{p}- \\
\text { value }\end{array}$ \\
\hline Taste (Delicious) & $467(28.3)$ & $167(21.8)$ & $<0.001$ \\
\hline Offers (toys and freebies) & $264(16.0)$ & $29(3.8)$ & $<0.001$ \\
\hline Health-related ingredients claim & $220(13.3)$ & $89(11.6)$ & 0.044 \\
\hline General health claims (part of healthy diet, balanced diet) & $158(9.6)$ & $175(22.9)$ & $<0.001$ \\
\hline Nutrient content claims (low energy, low fat cholesterol free) & $125(7.6)$ & $72(9.4)$ & 0.113 \\
\hline $\begin{array}{l}\text { Nutrient comparative claims (increased calcium content, reduced } \\
\text { fat, etc.) }\end{array}$ & $62(3.8)$ & $0(0.0)$ & $<0.001$ \\
\hline Other claims (e.g. organic food) & $62(3.8)$ & $0(0.0)$ & $<0.001$ \\
\hline Preparation time (easy to prepare/ready to eat) & $59(3.6)$ & $51(6.7)$ & 0.004 \\
\hline Reduction of disease risk claims & $12(0.7)$ & $1(0.1)$ & 0.046 \\
\hline No selling point claimed & 219 (13.3) & $181(23.7)$ & $<0.001$ \\
\hline
\end{tabular}

$\dagger$ Number of advertisements in both youth and children channel was higher for this variable as there were advertisements in which more than one selling point was claimed

\section{DISCLOSURE}

The statements in this publication are the views of the authors and do not necessarily reflect the policies or the views of United Nations Children's Fund (UNICEF). The designations employed in this publication and the presentation of the material do not imply on the part of UNICEF the expression of any opinion whatsoever concerning the legal status of any country or area, or of its authorities or the delimitations of its frontiers.

\section{FUNDING}

None

\section{AUTHORSHIP CONTRIBUTIONS}

MA, SB, and VS conceptualized the study. SB, DB, HM \& SD contributed to study administration. SB and DB supervised data collection and management. $\mathrm{DB}, \mathrm{HM}$, and $\mathrm{SB}$ contributed to data analysis and interpretation of results. SB, DB, HM, and SD drafted the manuscript. MA and VS reviewed the manuscript critically for intellectual content. All authors reviewed the manuscript and approve its contents.

\section{COMPETING INTERESTS}

The authors completed the Unified Competing Interest form at www.icmje.org/coi_disclosure.pdf (available upon request from the corresponding author), and declare no conflicts of interest.

\section{CORRESPONDENCE TO:}

Ms. Shalini Bassi, MSc

Health Promotion Division

Public Health Foundation of India

Plot No. 47, Sector 44

Gurgaon, Haryana, 122002, India.

Shalini.bassi@phfi.org

Submitted: July 07, 2021 GMT, Accepted: August 23, 2021 GMT 


\section{REFERENCES}

1. World Health Organization. Obesity and overweight: Key facts. World Health Organisation. Published 2020. Accessed November 25, 2020. http s://www.who.int/news-room/fact-sheets/detail/obesit y-and-overweight

2. United Nations Development Programme. Goal 3: Good health and well-being. Accessed November 25, 2020. https://www.un.org/sustainabledevelopment/h ealth/

3. Black RE, Victora CG, Walker SP, et al. Maternal and child undernutrition and overweight in low-income and middle-income countries. Lancet.

2013;382(9890):427-451. doi:10.1016/S0140-6736(1 3)60937-X

4. NFHS 3. National Family Health Survey (NFHS-3), 2005-2006: INDIA. Published 2006. Accessed December 19, 2020. http://www.nfhsindia.org/

5. NATIONAL FAMILY HEALTH SURVEY (NFHS-4), 2015-16: INDIA. http://www.rchiips.org/nfhs

6. Comprehensive National Nutrition Survey (CNNS) National Report. https://nhm.gov.in/WriteReadData/18 92s/1405796031571201348.pdf

7. Vadehra S. Advertising to children in India. Young Consum. 2010;11(2):24-35. doi:10.1108/yc.2010.32111 bab.001

8. Wang N, Xu F, Zheng LQ, et al. Effects of television viewing on body fatness among Chinese children and adolescents. Chin Med J (Engl).

2012;125(8):1500-1503. doi:10.3760/cma.j.issn.036 6-6999.2012.08.024

9. Harris JL, Bargh JA. Television viewing and unhealthy diet: implications for children and media interventions. Health Commun. 2009;24(7):660-673. d oi:10.1080/10410230903242267

10. Swinburn BA, Caterson I, Seidell JC, James WPT Diet, nutrition and the prevention of excess weight gain and obesity. Public Health Nutr. 2004;7(1a):123-146. doi:10.1079/phn2003585

11. Pomeranz JL. Television food marketing to children revisited: The federal trade commission has the constitutional and statutory authority to regulate. J Law, Med Ethics. 2010;38(1):98-116. doi:10.1111/j.17 48-720X.2010.00470.X
12. Kaushal N, Dudeja P. Food Advertisements Boon or Bane: A Prevalence Study of Misleading Food Advertisements in India. J Child Obes. 2017;02(04). do $\underline{\mathrm{i}: 10.21767 / 2572-5394.100039}$

13. Vijayapushpam T, Maheshwar M, Rao DR. A Comparative Analysis of Television Food Advertisements Aimed at Adults and Children in India. Int J Innov Res Sci Eng. 2014;2:2347-3207. Accessed May 24, 2021. https://www.researchgate.ne t/publication/280216565_A_Comparative_Analysis_o f_Television_Food_Advertisements_Aimed_at_Adult s_and_Children_in_India

14. Data Insights - BARC India. Accessed January 5, 2020. https://www.barcindia.co.in/data-insights\#curr encydata

15. Ok MA, Ercan A, Kaya FS. A content analysis of food advertising on Turkish television. Health Promot Int. 2016;31(4):801-808. doi:10.1093/heapro/dav065

16. Kelly B. INFORMAS Protocol: Food Promotion Module: Food Marketing - Television Protocol. Published online December 2017. doi:10.17608/K6.AU CKLAND.5664706.V1

17. Food Safety and Standards (Advertising and Claims) Regulations, 2018.

18. Kotz K, Story M. Food advertisements during children's Saturday morning television programming: Are they consistent with dietary recommendations? J Am Diet Assoc. 1994;94(11):1296-1300. doi:10.1016/0 $\underline{002-8223(94) 92463-5}$

19. WHO NUTRIENT PROFILE MODEL FOR SOUTHEAST ASIA REGION. World Health OrganizationRegional Office for South East Asia Region. Published 2017. Accessed January 6, 2021. http://apps.who.int/b ookorders.

\section{GUIDELINES FOR USE OF NUTRITION AND HEALTH CLAIMS (CAC/GL 23-1997).}

21. Stata: Software for Statistics and Data Science. Verison 13. STATA Corps

22. Soni P, Vohra J. Targeting the young food consumer. Mark Intell Plan. 2014;32(5):630-645. doi:1 $\underline{0.1108 / \text { MIP-04-2013-0072 }}$

23. Latinoamericano CE, Rosario S, Fe C, Zapata ME. Food and beverage advertising on children's TV channels in Argentina: Frequency, duration, and nutritional quality. Arch Argent Pediatr. 2017;115(1). doi:10.5546/aap.2017.eng.28 
24. Ghosh R, Dubey MJ, Chatterjee S, Dubey S. Impact of Covid-19 on children: special focus on the psychosocial aspect. Minerva Pediatr. 2020;72(3):226-261. doi:10.23736/S0026-4946.20.058 $\underline{87-9}$

25. Trends in Exposure to TV Ads during Covid-19.; 2020. Accessed May 31, 2021. https://www.asa.org.uk/ resource/covid-19-advertising-trends.html

26. BARC. BARC. What young India watches! BARC Newsletter 2018, Issue 2. Published 2018. Accessed January 7, 2020. https://www.barcindia.co.in/newslett er/what-young-india-watches.pdf

27. Neve M. To Study the Impact of Television Advertising on Children for Confectionery Products in Jalgaon City. In: Conference: Entrepreneurship, Innovation \& Economic Growth in Digital Era. G.H. Raisoni Institute of Business Management; 2019. Accessed April 6, 2021. https://www.researchgate.net/ publication/337323554_To_Study the_Impact of Tele vision_Advertising_on_Children_for_Confectionery_Pr oducts_in_Jalgaon_City

28. Gupta S, Kalra S, Kaushik J, Gupta P. Content of food advertising for young adolescents on television. Indian J Community Med. 2017;42(1):43-45. doi:10.410 3/0970-0218.199800

29. Prathapan S, Wijewardena K, Low WY. Content Analysis of Food and Beverages Advertisements Targeting Children and Adults on Television in Sri Lanka. Asia-Pacific J Public Heal. 2016;28(1 Suppl):86S-92S. doi:10.1177/1010539515620481

30. Nasreddine L, Taktouk M, Dabbous M, Melki J. The extent, nature, and nutritional quality of foods advertised to children in Lebanon: The first study to use the WHO nutrient profile model for the Eastern Mediterranean Region. Food Nutr Res. 2019;63. doi:1 $\underline{0.29219 / \text { fnr.v63.1604 }}$

31. Malik G, Guptha CA. Impact of Promotional Campaigns Featuring Kids on the Purchase Behavior of Customers. IUP J Mark Manag. 2013;12(1):43-58. ht tps://papers.ssrn.com/sol3/papers.cfm?abstract_id $=22$ $\underline{45560}$
32. Kelly B, Vandevijvere S, Ng S, et al. Global benchmarking of children's exposure to television advertising of unhealthy foods and beverages across 22 countries. Obes Rev. 2019;20(S2):116-128. doi:10.1 111/obr.12840

33. Priya P, Baisya RK, Sharma S. Television advertisements and children's buying behaviour. Mark Intell Plan. 2010;28(2):151-169. doi:10.1108/026 $\underline{34501011029664}$

\section{Calvert E. CARTOON CHARACTERS AND FOOD:} JUST FOR FUN?; 2017.

35. Cairns G, Angus K, Hastings G. THE EXTENT, NATURE AND EFFECTS OF FOOD PROMOTION TO CHILDREN: A REVIEW OF THE EVIDENCE TO DECEMBER 2008. World Health Organization; 2009. $\underline{\mathrm{h}}$ ttps://www.who.int/dietphysicalactivity/Evidence_Up date_2009.pdf

36. Bacardí-Gascón M, Díaz-Ramírez G, López BC, Zuñiga EL, Jiménez-Cruz A. Tv food advertisements' effect on food consumption and adiposity among women and children in Mexico. Nutr Hosp. 2013;28(6):1900-1904. doi:10.3305/nh.2013.28.6.6966

37. Story M, French S. Food advertising and marketing directed at children and adolescents in the US. Int $J$ Behav Nutr Phys Act. 2004;1(1):3. doi:10.1186/1479-5 868-1-3

38. The Consumer Protection Act, 2019.; 2019. Accessed May 24, 2021. https://www.indiacode.nic.in/ bitstream/123456789/15256/1/a2019-35.pdf

39. Cable Television Networks (Amendment) Rules, 2009.; 2009. Accessed April 23, 2021. https://www.tra i.gov.in/sites/default/files/CableTelevisionNetworksR ules1994.pdf

40. Hawkes C. MARKETING FOOD TO CHILDREN: Changes in the Global Regulatory Environment. World Health Organization; 2004.

41. Musuwo N. International Policies to Reduce Childhood Obesity-a Health Action Campaign Review.; 2019. 